University of Wollongong

Research Online

Australian Institute for Innovative Materials -

Papers

Australian Institute for Innovative Materials

$1-1-2018$

CO2 electrolysis in seawater: calcification effect and a hybrid self-powered concept

Chong Yong Lee

University of Wollongong, cylee@uow.edu.au

Gordon G. Wallace

University of Wollongong, gwallace@uow.edu.au

Follow this and additional works at: https://ro.uow.edu.au/aiimpapers

Part of the Engineering Commons, and the Physical Sciences and Mathematics Commons

Research Online is the open access institutional repository for the University of Wollongong. For further information contact the UOW Library: research-pubs@uow.edu.au 


\title{
CO2 electrolysis in seawater: calcification effect and a hybrid self-powered concept
}

\author{
Abstract \\ Oceans are regarded as a sink for anthropogenic $\mathrm{CO} 2$; as such seawater provides an attractive electrolyte \\ for electrochemical $\mathrm{CO} 2$ reduction to value-added carbon-based fuels and chemical feedstocks. However, \\ the composition of seawater is inherently complex, containing multiple cations and anions that may \\ participate in the $\mathrm{CO} 2$ electroreduction reaction. Herein, examination of a nanoporous Ag electrocatalyst \\ in seawater reveals a significant influence of calcium ions on the electrochemical $\mathrm{CO} 2$ reduction \\ performance. Under the applied cathodic potential and in the presence of $\mathrm{CO} 2$, calcium ions in the \\ seawater result in calcium carbonate deposition onto the nanoporous $\mathrm{Ag}$, reducing active sites for $\mathrm{CO} 2$ \\ electroreduction. Mitigation of calcification would promote a stable $\mathrm{CO} 2$ electrolysis in seawater. A first \\ proof-of-concept self-powered hybrid $\mathrm{CO} 2$ electrolysis is demonstrated by the coupling of a $\mathrm{Mg}$ anode to \\ a nanoporous $\mathrm{Ag}$ cathode in $0.6 \mathrm{M} \mathrm{NaCl}$ or seawater. A spontaneous oxidation of a $\mathrm{Mg}$ alloy at the anode \\ drives cathodic reduction of $\mathrm{AgCl}$ to nanoporous $\mathrm{Ag}$, which electrocatalytically reduces $\mathrm{CO} 2$ to $\mathrm{CO}$. \\ Combining galvanic and electrolytic properties in a single electrochemical cell offers a general approach \\ for designing hybrid self-powered electrolysers. Strategies to overcome calcification such as removal of \\ calcium from the seawater and development of anti-calcifying electrocatalysts are needed to promote \\ practicability of seawater as an electrolyte in $\mathrm{CO} 2$ electroreduction technology. \\ Disciplines \\ Engineering | Physical Sciences and Mathematics

\section{Publication Details} \\ Lee, C. \& Wallace, G. G. (2018). CO2 electrolysis in seawater: calcification effect and a hybrid self-powered \\ concept. Journal of Materials Chemistry A, 6 (46), 23301-23307.
}




\section{Journal Name}

\section{COMMUNICATION}

\section{$\mathrm{CO}_{2}$ electrolysis in seawater: calcification effect and a hybrid self-powered concept}

Received 00th January 20xx, Accepted 00th January 20xx

DOI: $10.1039 / x 0 x \times 00000 x$

\author{
Chong-Yong Lee, ${ }^{* a}$ and Gordon G Wallace*a
}

www.rsc.org/

Oceans are regarded as a sink for anthropogenic $\mathrm{CO}_{2}$, as such seawater provides an attractive electrolyte for electrochemical $\mathrm{CO}_{2}$ reduction to value-added carbon-based fuels and chemical feedstocks. However, composition of seawater is inherently complex, containing multiple cations and anions that may participate in $\mathrm{CO}_{2}$ electroreduction reaction. Herein, examination of a nanoporous Ag electrocatalyst in seawater reveals significant influence of calcium ions towards electrochemical $\mathrm{CO}_{2}$ reduction performance. Under the applied cathodic potential and in the presence of $\mathrm{CO}_{2}$, calcium ions in the seawater resulting in calcium carbonate deposition onto the nanoporous $\mathrm{Ag}$, reducing active sites for $\mathrm{CO}_{2}$ electroreduction. Mitigation from calcification would promote a stable $\mathrm{CO}_{2}$ electrolysis in seawater. A first proof-ofconcept self-powered hybrid $\mathrm{CO}_{2}$ electrolysis is demonstrated by the coupling of a $\mathrm{Mg}$ anode to a nanoporous $\mathrm{Ag}$ cathode in $0.6 \mathrm{M}$ $\mathrm{NaCl}$ or seawater. A spontaneous oxidation of a $\mathrm{Mg}$ alloy at anode driving cathodic reduction of $\mathrm{AgCl}$ to nanoporous $\mathrm{Ag}$, which electrocatalytically reduces $\mathrm{CO}_{2}$ to $\mathrm{CO}$. Combining galvanic and electrolytic properties in a single electrochemical cell offers a general approach in designing hybrid self-powered electrolysers. Strategies to overcome calcification such as removal of calcium from the seawater, and development of anti-calcifying electrocatalyst are needed to promote practicability of seawater as an electrolyte in $\mathrm{CO}_{2}$ electroreduction technology.

\section{Introduction}

As part of a $\mathrm{CO}_{2}$ mitigation effort, the scientific community has long investigated a variety of approaches to capture and convert $\mathrm{CO}_{2}$ to value-added products. ${ }^{1-9}$ Electrochemical $\mathrm{CO}_{2}$ reduction is one such attractive approach. ${ }^{4-9}$ While enormous efforts have been devoted in

a.ARC Centre of Excellence for Electromaterials Science,

Intelligent Polymer Research Institute, AlIM, Innovation

Campus, University of Wollongong, Wollongong, NSW 2500, Australia.

Emails: cylee@uow.edu.au; gwallace@uow.edu.au

tElectronic Supplementary Information (ESI) available. See

DOI: $10.1039 / x 0 \times x 00000 x$ developing highly efficient and selective $\mathrm{CO}_{2}$ reduction electrocatalysts; examination on influence of the electrolytes has attracted growing interest. Dissolved ions in the electrolytes were reported affecting $\mathrm{CO}_{2}$ electroreduction performance via parameters such as solution's bulk/localised $\mathrm{pH}$ and conductivity, specific adsorption on catalyst, and alteration in catalyst surface morphologies..$^{7-9}$

Oceans currently absorb vast quantities of $\mathrm{CO}_{2}$ released mainly by the burning of fossil fuels. ${ }^{10-12} \mathrm{CO}_{2}$ dissolves into seawater where it reacts to initially form carbonic acid, before being converted in equilibrium to the hydrogen carbonate $\left(\mathrm{HCO}_{3}{ }^{-}\right)$and carbonate $\left(\mathrm{CO}_{3}{ }^{2-}\right.$ ) ions. Having absorbed $\sim 40 \%$ anthropogenic $\mathrm{CO}_{2}$ emissions, oceans acidity has increased by $26 \%$ since pre-industrial era, and this trend is expected to continue. ${ }^{10-12}$ As such, seawater represents an extremely attractive electrolyte for $\mathrm{CO}_{2}$ electroreduction: not only is it abundant, but its ability to serve as a sink for $\mathrm{CO}_{2}$ and has an inherently high ionic conductivity. However, to date, seawater has been employed as an electrolyte for electrocatalytic water oxidation and proton reduction, ${ }^{13-15}$ rarely for electroreduction of $\mathrm{CO}_{2}$

To the best our knowledge, the only reported use of seawater for electroreduction of $\mathrm{CO}_{2}$ is from Nakata et. al. ${ }^{16}$ They briefly used seawater as an electrolyte, and achieved a faradaic conversion efficiency of $36 \%$ in formaldehyde formation using a boron doped diamond (BDD) electrode. However, no elucidation of factors affecting the poor $\mathrm{CO}_{2}$ electroreduction performance was given, illustrating the complexity of such chemistry in the presence of the dissolved ions in seawater. Instead of an expensive BDD electrode; a cheaper, widely available and tunable nanostructured metallic based electrode with corrosion resistance feature would be desirable. We found that $\mathrm{Ag} / \mathrm{AgCl}$ is an attractive choice. $\mathrm{Ag} / \mathrm{AgCl}$ electrode is highly stable at wide range of chloride concentrations in electrochemical reference system. Interestingly, they served as a cathode material for water or seawater activated batteries; ${ }^{17-19}$ this may also offer an opportunity to integrate battery-type galvanic feature to the intended $\mathrm{CO}_{2}$ electroreduction process. More ever, halide-derived nanoporous $\mathrm{Ag}$ from $\mathrm{AgCl}$ is among the best performing $\mathrm{Ag}$-based electrocatalysts, ${ }^{20-27}$ exhibits outstanding performance with a high faradaic $\mathrm{CO}_{2}$ to $\mathrm{CO}$ conversion efficiency at a low overpotential. ${ }^{25-27}$ 
Electrochemical $\mathrm{CO}_{2}$ reduction is conventionally driven by the use of an external electricity. ${ }^{4-9,} 20-27$ If the electricity could instead be readily generated internally within an electrochemical cell for $\mathrm{CO}_{2}$ reduction, it offers an alternative simplified design of $\mathrm{CO}_{2}$ electrolyser with dual-functionality in electrical power and carbon-based fuel generations. We demonstrate here such a concept by coupling of a spontaneous anodic magnesium oxidation reaction that produces $\mathrm{H}_{2}$, whilst driving electroreduction of $\mathrm{CO}_{2}$ to $\mathrm{CO}$ at the Ag-based cathode in saline water including seawater. $\mathrm{Mg}$ was selected for this proofof-concept study as it is light-weight, environmental friendly, possesses high theoretical voltages, and has been employed as a standby power source in land, and also undersea power sources. ${ }^{28}$ In this communication, we examined and compared the $\mathrm{CO}_{2}$ electroreduction performance of nanoporous $\mathrm{Ag}$ in $3.5 \mathrm{wt} \% \mathrm{NaCl}$ and seawater, and investigated the influence of dissolved ions presence in the seawater. We also discussed the features of our proof-ofconcept self-powered hybrid system, and it broader range of implication.

\section{Results and discussion}

$\mathrm{Ag} / \mathrm{AgCl}$ electrodes employed in this work were prepared by a simple anodisation of $\mathrm{Ag}$ foils. Interplay of chloride concentrations and applied potentials not only allow rapid formation of $\mathrm{Ag} / \mathrm{AgCl}$ layers, but tunable surface morphologies. ${ }^{25}$ Considering the electrolytes for $\mathrm{CO}_{2}$ electroreduction were with salinity of $\sim 3.5 \mathrm{wt} \% \mathrm{NaCl}, 0.6 \mathrm{M} \mathrm{NaCl}$ was employed as an electrolyte for the anodic formation of $\mathrm{Ag} / \mathrm{AgCl}$ film. Figure S1 (ESI+) shows the representative SEM top and cross-sectional views of the $\mathrm{Ag} / \mathrm{AgCl}$ electrode formed in $0.6 \mathrm{M} \mathrm{NaCl}$ solution, at $1.0 \mathrm{~V}$ for $300 \mathrm{~s}$. A AgCl film of $\sim 10 \mu \mathrm{m}$ thick, with negligible nanosheets on the microstructure was obtained. Upon electrochemical reduction at $-1.4 \mathrm{~V}$ (vs. $\mathrm{Ag} / \mathrm{AgCl}(3 \mathrm{M} \mathrm{NaCl})$ ) for 900 s (Figure $\mathrm{S} 2, \mathrm{ESI}+$ ) to convert $\mathrm{AgCl}$ to $\mathrm{Ag}$, a halide-derived $\mathrm{Ag}$ with the nanoporous structures of around $120 \pm 50 \mathrm{~nm}$ (Figure 1f(i)) was formed.

We examine the performance of chloride-derived nanoporous $\mathrm{Ag}$ electrodes for cathodic $\mathrm{CO}_{2}$ reduction process. Figure 1a shows the plot of $\mathrm{CO}_{2}$ to $\mathrm{CO}$ conversion faradaic efficiency versus applied potential recorded under $1 \mathrm{~h}$ electrolysis in $3.5 \mathrm{wt} \% \mathrm{NaCl}$ and seawater, respectively. In $3.5 \mathrm{wt} \% \mathrm{NaCl}, \mathrm{CO}_{2}$ to $\mathrm{CO}$ conversion efficiencies were consistently above $90 \%$ up to $-1.1 \mathrm{~V}$, and dropped to $\sim 72 \pm 5 \%$ at $-1.0 \mathrm{~V}$ vs $\mathrm{Ag} / \mathrm{AgCl}(3 \mathrm{M} \mathrm{NaCl})$. In seawater, the conversion efficiency is strongly dependent on the applied potentials. The highest faradaic efficiency of $\sim 93 \pm 3 \%$ was achieved at $-1.2 \mathrm{~V}$, but dropped to $65 \pm 4 \%$ at $-1.1 \mathrm{~V}$. Noted that the electrolysis at these two potentials were stable over $1 \mathrm{~h}$ electrolysis, but at -1.3 $\mathrm{V}$ and above, electrocatalytic currents in the first $10 \mathrm{~min}$ were unstable (Figure S3a, ESI+). Concurrently, the faradaic efficiencies also dropped to about 85,70 and $50 \%$ at $-1.3 \mathrm{~V},-1.4 \mathrm{~V}$ and $-1.5 \mathrm{~V}$, respectively. The higher cathodic potentials enhanced the localised $\mathrm{pH}$ change, which may promote the precipitation of calcium carbonate on the electrocatalytic sites of nanoporous $\mathrm{Ag}$ that subsequently influencing the faradaic conversion efficiencies. $\mathrm{H}_{2}$ constitutes to the remaining percentage of the generated products in both $\mathrm{NaCl}$ and seawater electrolytes. No other gas or liquid phase product was detected.

We further examined the long-term stability of the reduced nanoporous Ag electrodes. Seawater as an electrolyte results in a much lower stability in comparison to the $3.5 \mathrm{wt} \% \mathrm{NaCl}$ (Figure 1b). The electrocatalytic current drop significantly in the first few hours, and further drop to negligible current density. At -1.20 V (Figure S3b, ESI + ), although a greater initial stability was achieved, but it also dropped substantially after the first $3 \mathrm{~h}$. In contrast, a $24 \mathrm{~h}$ electrolysis at $-1.40 \mathrm{~V}$ vs. $\mathrm{Ag} / \mathrm{AgCl}(3 \mathrm{M} \mathrm{NaCl})$ in $3.5 \mathrm{wt} \% \mathrm{NaCl}$, an 
excellent consistency in the catalytic current density is shown. The initial faradaic current efficiency for conversion of $\mathrm{CO}_{2}$ to $\mathrm{CO}$ is found to be $\sim 95 \%$, and dropped to $\sim 79 \%$ and $\sim 75 \%$ in $12 \mathrm{~h}$ and $24 \mathrm{~h}$, respectively. (a)

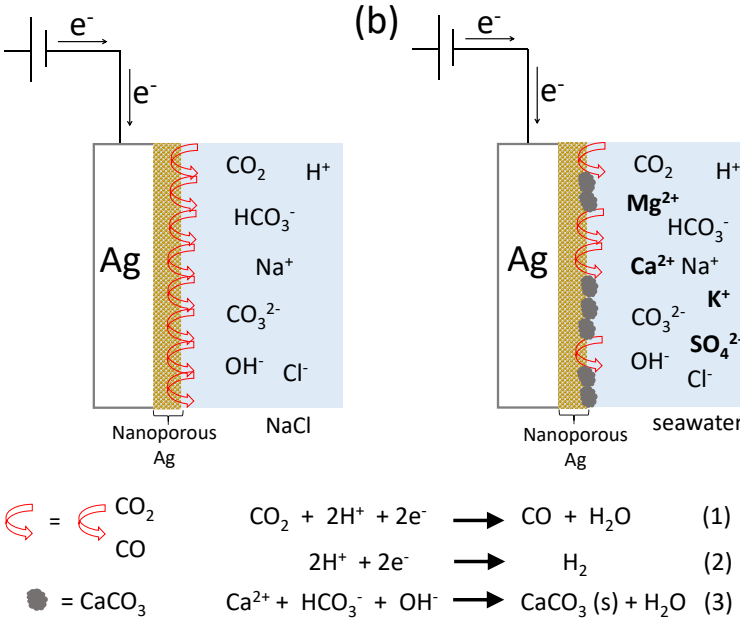

Figure 2 Schematic illustration of the interactions of dissolved ions in salt water (a) and seawater (b), under $\mathrm{CO}_{2}$ purging and an applied cathodic potential. In $\mathrm{NaCl}$ electrolyte, the competition to $\mathrm{CO}_{2}$ reduction (eq.1) is proton reduction reaction (eq. 2). The complexity of seawater as an electrolyte in the presence of several additional major ions is highlighted in bold (seawater also constitutes other $\sim 0.7 \%$ minor ions, which is not shown here). The applied cathodic potential induces localised $\mathrm{pH}$ change results in calcite precipitation on the nanoporous $\mathrm{Ag}$ (eq. 3 ). This reduces the available active sites of $\mathrm{Ag}$ to perform $\mathrm{CO}_{2}$ electoreduction (represents by red arrows).

A typical seawater consists of major dissolved ions such as $55 \%$ $\mathrm{Cl}^{-}, 30.6 \% \mathrm{Na}^{+}, 7.7 \% \mathrm{SO}_{4}{ }^{2-}, 3.7 \% \mathrm{Mg}^{2+}, 1.2 \% \mathrm{Ca}^{2+}$ and $1.1 \% \mathrm{~K}^{+} .29 \mathrm{To}$ elucidate the plausible reason for a lower stability and poorer performance of nanoporous $\mathrm{Ag}$ in the seawater, in addition to $~ 3.5$ wt $\% \mathrm{Na}^{+}, \mathrm{Cl}^{-}$; we introduced other seawater constituents $\mathrm{SO}_{4}{ }^{2-}, \mathrm{Mg}^{2+}$, $\mathrm{Ca}^{2+}$ and $\mathrm{K}^{+}$. The addition of $\mathrm{SO}_{4}{ }^{2-}, \mathrm{Mg}^{2+}$ and $\mathrm{K}^{+}$at $20 \mathrm{mM}$ did not affect the electrocatalytic current, and the CO conversion faradaic efficiencies (Figure S4, ESI+). However, introduction of $\mathrm{Ca}^{2+}$ resulted in a detrimental effect towards electrocatalytic $\mathrm{CO}_{2}$ reduction (Figure 1c). Increased concentration of the $\mathrm{CaCl}_{2}$ in the electrolyte from 10 $\mathrm{mM}$ to $20 \mathrm{mM}$ leads to a significant drop in the catalytic current.

XRD analysis in Figure $1 \mathrm{~d}$ indicates the formation of calcite for both reduced $\mathrm{Ag}$ electrodes in seawater and $3.5 \mathrm{wt} \% \mathrm{NaCl}$ solution intentionally added with $20 \mathrm{mM} \mathrm{CaCl}_{2}$. The diffraction intensity of calcite at (104) was the strongest, with other peaks at (013), (116), (018), (110) and (012). ${ }^{30}$ XRD data also indicates the expected reduction of $\mathrm{AgCl}$ to $\mathrm{Ag}$ upon the electro-reduction. ${ }^{25}$ Raman analysis performed using a laser of $638 \mathrm{~nm}$ presented in Figure 1e shows the principal Raman shift of $1086 \mathrm{~cm}^{-1}$, with weaker satellite peaks were observed with frequency shifts of $279 \mathrm{~cm}^{-1}$ and $710 \mathrm{~cm}^{-1}$, all indicating signature peaks of calcite. ${ }^{29}$ XPS analysis further confirms the formation of calcium calcite (Figure S5, ESI+). SEM images of Figure 1f shows structural change, with a larger particle size of nanoporous $\mathrm{Ag}$ obtained in $24 \mathrm{~h}$ (Figure $1 \mathrm{f}(\mathrm{ii})$ ) in comparison to the electrolysis in $3.5 \mathrm{wt} \% \mathrm{NaCl}$ for $1 \mathrm{~h}$ (Figure $1 \mathrm{f}(\mathrm{i})$ ). In seawater, there was a significant deposition of calcite with patch sizes of $\sim 10$ to 20 $\mu \mathrm{m}$ on the electrode surface (Figure 1f(iii), Figure S6, ESI+).

Supported by the evident of calcite formation, we propose that $\mathrm{Ca}^{2+}$ containing seawater results in an electrochemically driven calcite precipitation onto nanoporous $\mathrm{Ag}$ (Figure 2, eq. 3). The localised increase of the $\mathrm{pH}$ resulting from $\mathrm{CO}_{2}$ reduction at $\mathrm{Ag}$ active sites induces precipitation of calcite on the $\mathrm{Ag}$ catalyst. This is consistent with our $\mathrm{pH}$ measurement indicates decreased acidity of seawater as experiment progress. The type of substrate and hard water composition could significantly influence such electrochemical scaling process. ${ }^{31-32}$ In this study, nanoporous $\mathrm{Ag}$ in contact with seawater preferentially deposited calcite, and this process is competing with $\mathrm{CO}_{2}$ and $\mathrm{H}^{+}$reduction reactions (eq. 1 and 2 ). As such, the available $\mathrm{Ag}$ active sites for $\mathrm{CO}_{2}$ electroreduction decreased gradually with the increment of deposit.

(a)

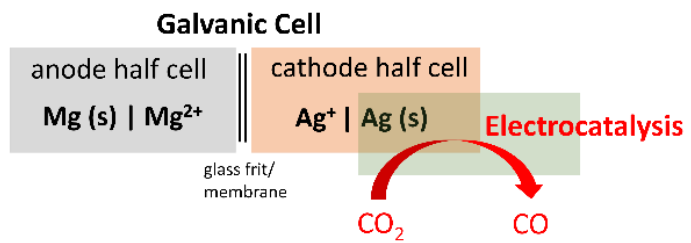

(b)

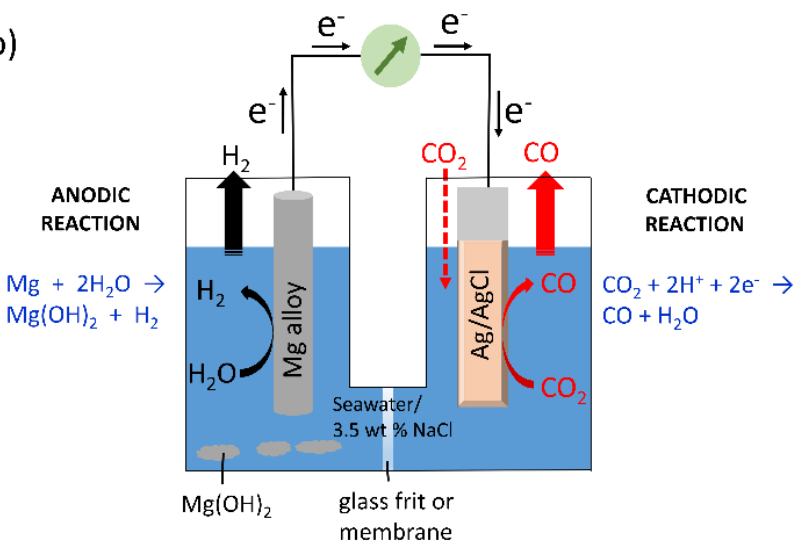

Figure 3 (a) Diagram of a galvanic cell consisting of a $\mathrm{Mg}$ as anodic half-cell that is oxidize to $\mathrm{Mg}^{2+}$, and $\mathrm{Ag}^{+}$is reduce to $\mathrm{Ag}$ at the cathodic half-cell. An overlapping box to the cathodic half reaction represents an electrolytic process of catalytic conversion of $\mathrm{CO}_{2}$ to $\mathrm{CO}$ by the reduced $\mathrm{Ag}$. (b) Schematic diagram of the assembly of an electrochemical cell to generate $\mathrm{H}_{2}$ and $\mathrm{CO}$. Anodic and cathodic compartments were consisting of a $\mathrm{Mg}$ alloy and a $\mathrm{Ag} / \mathrm{AgCl}$ electrodes, respectively.

Taking advantage of the feasibility of the $\mathrm{CO}_{2}$ electroduction in saline water, we examine the possibility of driving cathodic reaction by coupling with an anodic process which could generate galvanic currents. Such a hybrid concept of a galvanic reaction driven an electrolytic process is illustrated in Figure 3. A galvanic cell is consisting of two half-cells connected by a membrane or a glass frit; a $\mathrm{Mg}$ and a $\mathrm{Ag}^{+}$(eg. $\mathrm{AgCl}$ in this work) serve as an anode and a cathode, respectively. A Mg anode in a salt containing electrolyte is spontaneously oxidise to $\mathrm{Mg}^{2+}, 33-35$ and the electrons resulting from the galvanic reaction flow to cathode for electroreduction of $\mathrm{Ag}^{+}$to Ag. In the presence of $\mathrm{CO}_{2}$ as a reactant at the cathodic compartment, the reduced $\mathrm{Ag}$ acts as an electrocatalyst converts $\mathrm{CO}_{2}$ 
to $\mathrm{CO}$. This half-cell electrolytic reaction of $\mathrm{CO}_{2}$ catalytic conversion is therefore powered by an internal galvanic cell.

Figure $4 a$ illustrates the electrochemical behavior of the proposed cell-assembly via a combine plot from half-cell studies of cathodic $\mathrm{CO}_{2}$ reduction and anodic $\mathrm{Mg}$ oxidation processes. Evidently, as an oxidation of $\mathrm{Mg}$ occurs at a more negative potential than cathodic $\mathrm{CO}_{2}$ reduction process; spontaneously oxidative process is readily generating electricity within the assembled cell to drive the cathodic $\mathrm{CO}_{2}$ reduction to $\mathrm{CO}$ by the nanoporous $\mathrm{Ag}$. In contrast, a typical $\mathrm{CO}_{2}$ reduction electrochemical device exhibits a more positive anodic potential than that the counterpart cathodic reaction, whereby the potential difference determines the external bias potential needed to drive the reaction. ${ }^{36,37}$

To examine the concept of a self-powered system; anode and cathode in a two-compartmented cell was wiring with crocodile clips, without loading any external electrical power supply (Figure S7, Video S1, ESI †). Our examination of an open circuit potential of the cell assembly in a two-compartment configuration show the value of $\sim 1.58 \mathrm{~V} \pm 0.04$ with the used of $\mathrm{Ag} / \mathrm{AgCl}$ electrode (Figure $\mathrm{S} 8, \mathrm{ESI}+$ ). Upon the electrical connection, $\mathrm{AgCl}$ film was gradually reduced to nanoporous $\mathrm{Ag}$ as evidenced by a brownish $\mathrm{AgCl}$ changed to a silvergrey $\mathrm{Ag}$. This conversion process to produce electrocatalytically active nanoporous $\mathrm{Ag}$ is typically completed around 20 minutes. This step was identical to the chronopotentiometry measurement (Figure S9, $\mathrm{ESI}+$ ), but the electroreduction of $\mathrm{AgCl}$ instead was driven by electrons generated from the spontaneous oxidation of $\mathrm{Mg}$. The galvanic current then proceed to drive the $\mathrm{CO}_{2}$ electroreduction at the reduced nanoporous Ag. As illustrated in Figure $1 \mathrm{~b}, \mathrm{H}_{2}$ and $\mathrm{CO}$ was generated simultaneously in the anodic and cathodic compartments, respectively.
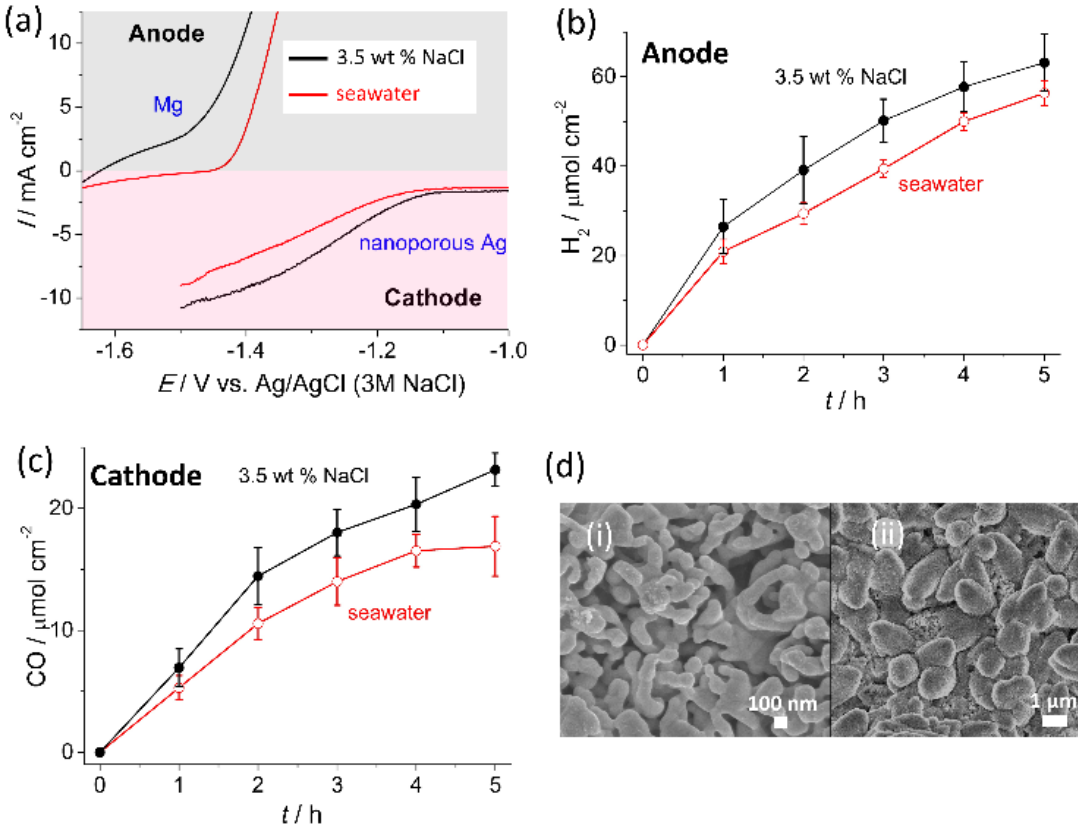

(d)

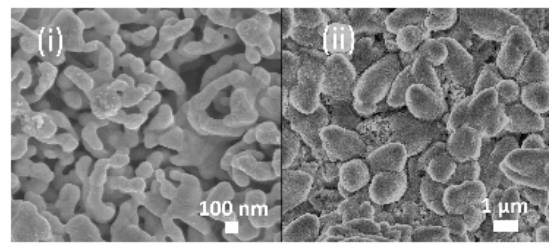

Figure 4 (a) The voltammograms recorded in a three-electrode configuration for anodic oxidation of a $\mathrm{Mg}$ alloy, and cathodic $\mathrm{CO}_{2}$ reduction on a chloride-derived nanoporous $\mathrm{Ag}$, in $3.5 \mathrm{wt} \% \mathrm{NaCl}$ and seawater. Plots of moles of $\mathrm{H}_{2}$ (b) and $\mathrm{CO}$ (c) obtained from the anodic and cathodic compartments, over $5 \mathrm{~h}$ self-powered full-cell assembly. (d) Representative SEM images of the $\mathrm{Ag} / \mathrm{AgCl}$ samples after electroreduction in the self-powered full-cell assembly in $3.5 \mathrm{wt} \% \mathrm{NaCl}$ (i) and seawater (ii).
We collected and quantified the $\mathrm{H}_{2}$ and $\mathrm{CO}$ gases, with the plots of moles of generated $\mathrm{H}_{2}$ and $\mathrm{CO}$ are shown in Figures $4 \mathrm{~b}$ and $4 \mathrm{c}$. As a result of oxidation of $\mathrm{Mg}$ alloy, $\mathrm{H}_{2}$ was generated spontaneously and increased with time. $\mathrm{Mg}$ alloy in $3.5 \mathrm{wt} \% \mathrm{NaCl}$ produced more $\mathrm{H}_{2}$ in comparison to the seawater as anodic dissolution was faster in this medium. Consequently, CO production in seawater was lesser than that in $3.5 \mathrm{wt} \% \mathrm{NaCl}$. Although with a slower production rate as the experiment progress, $\mathrm{CO}$ was continually generated up to $\sim 4$ $h$ in seawater which implies a slower rate of calcite deposition on the Ag surface in this self-powered assembly. Otherwise, a poorer stability of the nanoporous $\mathrm{Ag}$ with a quicker decay of $\mathrm{CO}$ production may occur, as was the case of half-cell study of $\mathrm{CO}_{2}$ electroreduction at $-1.4 \mathrm{~V}$ in seawater (Figure $2 \mathrm{~b}$ ). In additional to $\mathrm{CO}$, a small amount of $\mathrm{H}_{2}$ was also generated in the cathodic compartment (see Figure $\mathrm{S} 10, \mathrm{ESI}+$ ), with no other product was detected. Control experiments with bare $\mathrm{Ag}$ foils in $3.5 \mathrm{wt} \% \mathrm{NaCl}$ and seawater produce a very small quantity of $\mathrm{CO}$ (less than $1 \mu \mathrm{mol} \mathrm{cm}{ }^{-2}$ after $5 \mathrm{~h}$ electrolysis), indicating the role of nanoporous $\mathrm{Ag}$ in activation of $\mathrm{CO}_{2}$ electroreduction.

Comparison of SEM images of the Ag electrodes after $5 \mathrm{~h}$ electrolysis is shown in Figure 4d. A nanoporous feature was observed for the reduced $\mathrm{Ag}$ electrode performed in a $\mathrm{NaCl}$ electrolyte. However, in seawater, a larger feature sizes around 1 to $2 \mu \mathrm{m}$ was observed that indicated the deposition of calcite onto the reduced nanoporous Ag. This is confirmed by detection of peaks corresponding to calcite from XRD and Raman data (Figure S11, ESI+). For the anodic part, XRD of Figure S12 (ESI+) confirmed the byproduct from the oxidation of $\mathrm{Mg}$ producing $\mathrm{Mg}(\mathrm{OH})_{2}$.

We show in this study the suitability of $\mathrm{AgCl}$-derived nanoporous $\mathrm{Ag}$ to operate for $\mathrm{CO}_{2}$ electroreduction to $\mathrm{CO}$ in saline electrolyte. The halide-derived electrocatalyst including $\mathrm{AgCl}$ has been reported offered an advantage of significantly suppress hydrogen evolution reaction..$^{25-27}$ The reaction mechanism is believed involving a multiple-step overall two-electron reduction of $\mathrm{CO}_{2}$ to $\mathrm{CO}$ process as described in the previous studies. ${ }^{20,} 26$ In salt water, high selectivity towards CO production (> $90 \%$ conversion efficiency) was achieved, with the retention of faradaic efficiency of up to $\sim 75 \%$ over one day of electrolysis. CO conversion faradaic efficiency of $90 \%$ was achieved at $-1.2 \mathrm{~V}$ vs $\mathrm{Ag} / \mathrm{AgCl}(3 \mathrm{M} \mathrm{NaCl})$ in seawater, but with reduced long-term stability. The presence of calcium in seawater is found not only decreased the stability of the $\mathrm{Ag}$ catalyst; but also decreased the selectivity in $\mathrm{CO}$ conversion. To minimise the impact of $\mathrm{Ca}^{2+}$ in seawater in the direct electrochemical $\mathrm{CO}_{2}$ conversion, existing technologies, such as ion exchange resins, 38,39 and precipitation agents ${ }^{40}$ are readily available to remove $\mathrm{Ca}^{2+}$ from seawater before being employed as an electrolyte.

In our proof-of-concept demonstration of a selfpowered hybrid system, we employed a magnesium alloy to serve as the anode. This serves two purposes: its direct reaction with saline water spontaneously generate $\mathrm{H}_{2}$, producing $\mathrm{Mg}(\mathrm{OH})_{2}$ that precipitates in the solution as the sole byproduct; and its high activity drives a galvanic current that ultimately reduces $\mathrm{CO}_{2}$. The rate limiting factor of the present system was the longterm stability of the halide-derived $\mathrm{Ag}$ catalyst in 
performing $\mathrm{CO}_{2}$ reduction, as excess of electrons were generated from the anodic dissolution of $\mathrm{Mg}$. $\mathrm{Mg}$ in this demonstration is serving as a primary cell, where the spent $\mathrm{Mg}$ anode can be replaced, as is the case of Mg-based battery systems. ${ }^{28}$

Our proposed compartmented self-powered electrochemical cel facilitates the coupling of various anode and cathode materials, therefore it is important to emphasis that the self-powered concept demonstrated here is not limited to the use of $\mathrm{Mg}$ as an anode, or $\mathrm{Ag} / \mathrm{AgCl}$ as a cathode. As $\mathrm{Mg}$ production is relatively energyintensive, other sustainable anode materials that generating valuable anodic products would be desirable. $\mathrm{Ag} / \mathrm{AgCl}$ employed as a cathode for $\mathrm{CO}_{2}$ reduction in this work generates $\mathrm{CO}$ through two proton-coupled electron transfers. Other $\mathrm{CO}_{2}$ reduction electrocatalyst materials that capable in generation of long chain $\left(\mathrm{C}_{4^{-}}\right.$ $C_{12}$ ) carbon products which consumed up to 12 electrons could be examined for in this hybrid system. .11,42 $^{4}$

As more efficient $\mathrm{CO}_{2}$ reduction electrocatalysts to accommodate wide-ranging products are expected to be developed as the field progress; such a self-powered concept could serve to accommodate ad hoc and tasked-specific generation of desirable carbon-based products. For example, accessibility to electricity maybe limited in remote, undersea and military areas; this technology offers dual functionalities where the users could generate electricity and/or desirable carbon-based fuels. The required $\mathrm{CO}_{2}$ could be integrated and sourced from the advanced materials that capable of releasing the stored $\mathrm{CO}_{2} \cdot{ }^{1}{ }^{43}$ Hence, the proposed self-powered concept is intended to serve as a portable system for tasked-specific niche applications. This is a complimentary technology to the large-scale carbon-based fuel generation approach powered by an external renewable electricity, such as from solar and wind, with $\mathrm{CO}_{2}$ obtained from the fossil fuel power plant Importantly, recent advances in aqueous-based magnesium and other metallic secondary cell batteries, ${ }^{28,44-46}$ offers a prospect to further advance such a self-powered concept to be rechargeable; where one could store the renewable electricity, and generating carbon-based fuels in a single aqueous-based electrochemical cell.

\section{Conclusions}

In summary, seawater is employable as an electrolyte for $\mathrm{CO}_{2}$ electroreduction. Calcium ions in the seawater could be viewed as an undesirable interference species with respect to durability and efficiency of a $\mathrm{CO}_{2}$ reduction electrocatalyst; in contrast, its high affinity for $\mathrm{CO}_{2}$ means that it may serve as a useful species to electrochemically capture and store $\mathrm{CO}_{2}$. A follow-up study will focus towards two key directions: finding an effective and simple strategy to remove calcium from the seawater, and developing anticalcification coating on the electrocatalyst; with the aim of achieve a long-term stable and durable $\mathrm{CO}_{2}$ electroreduction in seawater. The first proof-of-concept self-powered aqueous-based $\mathrm{CO}_{2}$ electrolyser that we presented here is readily extendable to the rational coupling of other anodes and cathodes that could trigger both galvanic and targeted electrocatalytic reactions. Future work by the incorporation of an aqueous-based secondary battery feature would allow a rechargeable self-powered $\mathrm{CO}_{2}$ electrolyser concept. Renewable electricity could be stored to power the electrolyser, hence advocating a sustainable system in electricity storage and renewable fuels generation within a single electrochemical cell.

\section{Conflicts of interest}

There are no conflicts to declare.

\section{Acknowledgements}

This work was supported by the University of Wollongong's Vice Chancellor Research Fellowship (to CYL). Funding from the Australian Research Council Centre of Excellence Scheme (CE 140100012) is gratefully acknowledged. The authors would also like to thank Australian National Fabrication Facility-Materials Node (ANFF) and UOW Electron Microscopy Centre for equipment use. We thank John Bullock (Bennington College) for his useful comments on this manuscript.

\section{References}

1. M. Aresta, A. Dibenedetto and A. Angelini, Chem. Rev., 2014, 114, 1709.

2. J. Artz, Chem. Rev., 2018, 118, 434

3. D. P. Schrag, Science, 2007, 315, 812

4. J. H. Montoya, L. C. Seitz, P. Chakthranont, A. Vojvodic, T. Jaramillo and J. K. Nørskov, Nat. Mater., 2017, 16, 70.

5. C. W. Li and M. W. Kanan, J. Am. Chem. Soc., 2012, 134, 7231.

6. S. Gao, Y. Lin, X. Jiao, Y. Sun, Q. Luo, W. Zhang, D. Li, J. Yang and Y. Xie, Nature, 2016, 529, 68.

7. C.-T. Dinh, T. Burdyny, Md. G. Kibria, A. Seifitokaldani, C. M. Gabardo, F. P. G. d. Arquer, A. Kiani, J. P. Edwards, P. D. Luna, O. S. Bushuyev, C. Zou, R. Quintero-Bermudez, Y. Pang, D. Sinton and E. H. Sargent, Science, 2018, 360, 783.

8. S. Verma, X. Lu, S. Ma, R. I. Masel and P. J. A. Kenis, Phys. Chem. Chem. Phys., 2016, 18, 7075.

9. M. R. Singh, Y. Kwon, Y. Lum, J. W. Ager and A. T. Bell, J. Am. Chem. Soc., 2016, 138, 13006.

10. S. Khatiwala, T. Tanhua, S. M. Fletcher, M. Gerber, S. C. Doney, H. D. Graven, N. Gruber, G. A. McKinley, A. Murata, A. F. Rios and C. L. Sabine, Biogeosciences, 2013, 10, 2169.

11. T. Devries, M. Holzer and F. Primeau, Nature, 2017, 542, 215.

12. K. Caldeira and M. E. Wickett, Nature, 2003, 425, 365.

13. S. Fukuzumi, Y.-M. Lee and W. Nam, ChemSusChem, 2017, 10, 4264

14. F. Dionigi, T. Reier, Z. Pawolek, M. Gliech and P. Strasser, ChemSusChem, 2016, 9, 962.

15. N. Jiang and H.-M. Meng, Surf. Coat. Techn., 2012, 206, 4362.

16. K. Nakata, T. Ozaki, C. Terashima, A. Fujishima and Y. Einaga, Angew. Chem. Int. Ed., 2014, 53, 871.

17. I. C. Blake, J. Electrochem. Soc., 1952, 99, 202c.

18. J. B. Mullen and P. L. Howard, J. Electrochem. Soc. 1946, 90 520.

19. K. V. Rao, Def. Sci. J., 2001, 51, 161.

20. Y. Hori, in Modern Aspects of Electrochemistry, Volume 42 (Eds.: C. G. Vayenas, R. E. White; M. E. Gamboa-Aldeco), Springer New York, New York, USA, 2008, Ch. 3

21. Q. Lu, J. Rosen, Y. Zhou, G. S. Hutchings, Y. C. Kimmel, J. G. Chen and F. Jiao, Nat. Commun., 2014, 5, 3242.

22. L. Q. Zhou, C. Ling, M. Jones and H. Jia. Chem. Commun., 2015, 51, 17704.

23. C. Kim, H. S. Jeon, T. Eom, M. S. Jee, H. Kim, C. M. Friend, B. K. Min and Y. J. Hwang, J. Am. Chem. Soc., 2015, 137, 13844.

24. M. Ma, B. J. Trześniewski, J. Xie and W. A. Smith, Angew. Chem. Int. Ed., 2016, 128, 9900.

25. C.-Y. Lee, Y. Zhao, C. Wang, D. G. Mitchell and G. G. Wallace, Sustainable Energy Fuels, 2017, 1, 1023.

26. Y.-C. Hsieh, S. D. Senanayake, Y. Zhang, W. Xu and D. E. Polyansky, ACS Catal., 2015, 5, 5349. 
27. L. Zhang, Z. Wang, N. Mehio, X. Jin and S. Dai, ChemSusChem, 2016, 9, 428.

28. T. Zhang, Z. Tao and J. Chen, Mater. Horizons, 2014, 2, 149.

29. M. E. Q. Pilson, (1998). An introduction to the chemistry of the sea, Prentice Hall, N. J.

30. C. G. Kontoyannis and N. V. Vagenas, Analyst, 2000, 125, 251.

31. C. Gabrielli, R. Jaouhari, S. Joiret, G. Maurin and P. Rousseau, J. Electrochem. Soc., 2003, 150, C478.

32. R. Jaouhari, A. Benbachir, A. Guenbour, C. Gabrielle, J. GarciaJareno and G. Maurin, J. Electrochem. Soc., 2000, 147, 2151.

33. A. Pardo, M. C. Merino, A. E. Coy, R. Arrabal, F. Viejo and E. Matykina. Corros. Sci., 2008, 50, 823.

34. N. Birbilis, M. K. Cavanaugh, A. D. Sudholz, S. M. Zhu, M. A. Easton and A. Gibson. Corros. Sci., 2011, 53, 168.

35. Z. X. Qiao, Z. M. Shi, N. Hort, N. I. Z. Abidin and A. Atrens, Corros. Sci., 2012, 61, 185.

36. D. A. Vermass and W. A. Smith, ACS Energy Lett., 2016, 1, 1143.

37. Y. C. Li, D. Zhou, Z. Yan, R. H. Goncalves, D. A. Salvatore, C. Berlinguette and T. E. Mallouck, ACS Energy Lett., 2016, 1, 1149.

38. H. R. Flodman and B. I. Dvorak, Water Environ. Res., 2012, 84, 535.

39. D. Clifford, T. J. Sorg and G. L. Ghurye, Ion exchange and adsorption of inorganic contaminants, in: J. K. Edzwald (Ed.) Water Quality \& Treatment: A Handbook on Drinking Water, McGraw-Hill Inc., New York, NY, 2011.

40. R. I. Jeldres, M. P. Arancibia-Bravo, A. Reyes, C. E. Aguirre, L. Cortes and L. A. Cisternas, Miner. Eng., 2017, 109, 10.

41. B. Khezri, A. C. Fisher and M. Pumera, J. Mater. Chem. A., 2017, 5, 8230 .

42. O. S. Bushuyev, P. D. Luna, C. T. Dinh, L. Tao, G. Saur, J. v. d. Lagemaat, S. O. Kelly and E. H. Sargent, Joule, 2018, 2, 825.

43. M. E. Boot-Handford, J. C. Abanades, E. J. Anthony, M. J. Blunt, S. Brandani, N. Mac Dowell, J. R. Fern'andez, M.-C. Ferrari, R. Gross, J. P. Hallett, R. S. Haszeldine, P. Heptonstall, A. Lyngfelt, Z. Makuch, E. Mangano, R. T. J. Porter, M. Pourkashanian, G. T. Rochelle, N. Shah, J. G. Yao and P. S. Fennell, Energy Environ. Sci. 2014, 7, 130.

44. F. Wang, X. Fan, T. Gao, W. Sun, Z. Ma, C. Yang, F. Han, K. Xu and C. Wang, ACS Cent. Sci. 2017, 3, 1121.

45. W. Ma, X. Liu, C. Li, H. Yin, W. Xi, R, Liu, G. He, X. Zhao, J. Luo and Y. Ding, Adv. Mater. 2018, 30, 1801152.

46. J. Liu, C. Xu, Z. Chen, S. Ni and Z. X. Shen, Green Energy \& Environ. 2018, 3, 20-41. 